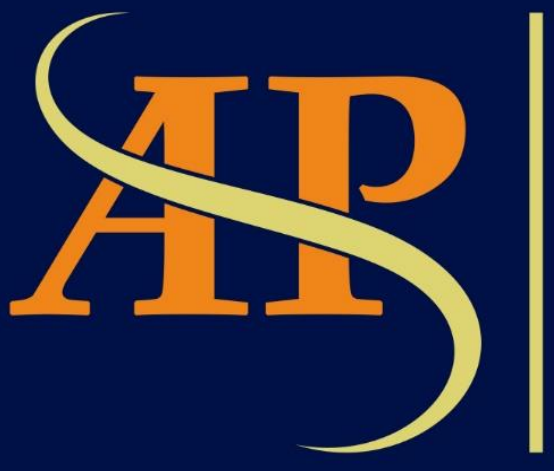

JURNAL

ASIA

PACIFIC

STUDIES

Journal of International Relations Study Program Faculty of Social and Political Sciences

Universitas Kristen Indonesia

Volume I | Number 1 | January- June 2017 


\title{
PROTEKSIONISME SENGKETA DAGANG DALAM PERDAGANGAN INTERNASIONAL: PENDEKATAN NEGOSIASI STUDI KASUS: PROTEKSIONISME AS TERHADAP IMPOR DAGING KANADA
}

\author{
Laode Muhamad Fathun \\ Prodi Hubungan Internasional , FISIP UPN "Veteran "Jakarta, Jl. Fatmawati No.1 Pondok Labu Jakarta \\ Selatan 12450
}

$\underline{\text { Lm_fathun@yahoo.co.id/fathun.Im@upnvi.ac.id }}$

\begin{abstract}
This paper will explain the problem of dispute in international trade and the role of the World Trade Organization (WTO) as a mediator in the dispute. Economic globalization and international trade relations through free market has positive and negative impact. They are the consequences of countries becoming members of the WTO. Trade protectionism is an unfair form of anti-free market policy in the international market. This policy is to protect a country's domestic market but on the other hand it reduced the spirit of the free market. Protection is often done by complicating administrative documents, quota, product certification, health aspect, labor protection. A protectionist policy has been made by the United States in the case of importing meat from Canada where WTO as a mediator and international trade regime becomes the dominant actor in the negotiation process. As a result, the United States cannot prove the state's allegation against Canadian meat imports after a special panel was conducted in a session at the Dispute Settlement Body (DSB). Therefore the protectionist policy must be rational and accountable so that no country will be harmed by its impact either in the micro scale (consumer) or the macro scale (country).
\end{abstract}

Keywords: Economic Development, Trade Globalization, Free Trade, Trade Barriers, Protectionism, WTO.

\begin{abstract}
Abstrak
Makalah ini akan menjelaskan masalah perselisihan dalam perdagangan internasional dan peran World Trade Organization (WTO) sebagai mediator dalam perselisihan tersebut. Globalisasi ekonomi dalam bentuk hubungan perdagangan internasional melalui slogan pasar bebas telah memberikan dampak positif maupun negatif. Kondisi itu merupakan konsekuensi dari negara-negara yang menjadi anggota WTO untuk menciptakan pasar yang kompetitif. Proteksionisme perdagangan merupakan bentuk kebijakan anti-pasar bebas yang tidak adil dalam pasar internasional. Kebijakan ini dilakukan untuk melindungi pasar dalam negeri yang di lain pihak mengurangi semangat pasar bebas. Perlindungan sering dilakukan dengan menerapkan aturan dokumen administrasi, jumlah kuota, sertifikasi produk, aspek kesehatan, proteksi tenaga kerja sebagai cara negara melindungi pasar domestiknya. Salah satu contoh adalah kebijakan yang pernah dilakukan oleh Amerika Serikat terhadap impor daging dari Kanada dimana WTO sebagai mediator dan rezim perdagangan internasional menjadi aktor dominan dalam proses negosiasi. Hasilnya Amerika Serikat tidak bisa membuktikan tuduhan terhadap impor daging Kanada setelah dilakukan panel khusus dalam sidang di Dispute Settlement Body (DSB) atau Badan Penyelesaian Persengketaan WTO. Jadi kebijakan proteksionis harus rasional dan bisa dipertanggungjawabkan sehingga tidak ada satu negara pun yang dirugikan oleh dampak kebijakan tersebut baik pada skala mikro (konsumen) maupun skala makro (negara).
\end{abstract}

Kata kunci: Perkembangan Ekonomi, Globalisasi Perdagangan, Perdagangan Bebas, Hambatan Perdagangan, Proteksionisme, WTO 


\section{Latar Belakang}

Dalam perkembangan perdagangan ekonomi politik global melalui kerangka neo liberal di abad 21 ini, terdapat kecenderungan bahwa setiap negara terlibat dalam persaingan pasar bebas atau dikenal dengan free trade competition. Akibatnya, setiap negara diwajibkan untuk mengikuti slogan pasar terbuka (open market) dan harus menyesuaikan diri dengan sejumlah aturan yang cenderung menghalangi kebebasan pasar dalam mekanisme ekonomi politik global. Negara seolah diwajibkan untuk terbuka dan membuka pasar domestiknya tanpa terkecuali terhadap masuknya sejumlah produk-produk ekspor negara lain dan tentunya dengan konsekuensi menghapuskan hambatan-hambatan perdagangan bebas dalam percaturan ekonomi politik global. Hambatan-hambatan masa lalu seperti tarif, kuota, regulasi, bukan lagi hambatan berarti untuk terjadinya global free market di era globalisasi dewasa ini. Munculnya kebijakan tersebut bukan hanya di tujukan kepada sejumlah negara maju atau negara-negara utara seperti Amerika Serikat (AS), Eropa, Rusia tetapi juga negara-negara berkembang yang juga menjadi sasaran, dengan asumsi bahwa negara-negara berkembang inilah yang selalu menerapkan politik proteksionisme untuk melindungi sejumlah industri domestik yang dianggap sangat tertutup terhadap kebijakan pasar bebas.

Oleh sebab itu negara-negara maju yang cenderung kekurangan sumber daya alam berupaya sekuat tenaga untuk melakukan lobi-lobi agar setiap negara memberikan akses seluas-luasnya untuk terjadinya kompetisi pasar bebas. Walaupun demikian permainan politik proteksionisme adalah upaya sebuah negara untuk melindungi atau menutup keran pasar domestiknya dengan asumsi bahwa produk-produk dalam negeri bisa dilindungi atau diciptakan agar tidak terlindas oleh masuknya produk-produk ekspor/impor dari negara asing dan nantinya diharapkan bisa bersaing dalam kompetisi global.

Munculnya instrumen politik proteksionisme ini apabila dilihat prakteknya di negaranegara berkembang lebih condong sebagai upaya melindungi hard market. Maksudnya adalah negara berkembang tidak siap secara implisit untuk membuka pasar dengan alasan industri bawah dan menengah akan cenderung tergilas oleh masuknya produk asing. Sedangkan negara maju menggunakan instrumen soft market untuk melindungi pasar domestiknya dengan berbagai alasan seperti faktor kesehatan, perburuhan, agama, rasisme dan lain sebagainya. Stabilitas pasar domestik dengan instrumen non trade atau dikenal dengan non-tariff barriers menjadi pemicu sejumlah low conflict dalam skala global, dimana proteksionisme menjadi instrumen ekonomi politik sejumlah negara yang cenderung bisa menjadi regulasi baru atau contoh baru dalam praktek ekononomi politik global terutama untuk penyelesaian sengketa dalam bentuk diplomasi multilateral.

Sengketa perdagangan internasional dalam permainan ekonomi politik global kontemporer sudah menjadi hal lazim apabila konflik tersebut dibawa pada sebuah badan yang diasumsikan netral sebagai mediator (peace maker) dalam menanggulangi sejumlah kasus low conflict seperti kasus perdagangan bebas. World Trade Organization (WTO) merupakan sebuah lembaga yang diasumsikan sangat netral sebagai sebuah rezim organisasi internasional yang memiliki wewenang untuk mengatasi sejumlah sengketa dagang diantara negara-negara anggotanya. Data yang dirilis oleh WTO tentang proteksionisme sejumlah negara dari tahun 1995-2011 seolah sudah menjadi instrumen ekonomi politik yang lumrah dilakukan oleh setiap negara. Tercermin dari banyaknya kasus yang terjadi dalam sengketa dagang seperti sengketa antara AS dan Brazil pada tahun 1995 tentang Gasoline, antara Jepang dan Kanada tentang Alcoholic Beverages dalam periode 1995-1996, antara Australia dan Kanada tentang Salmon pada tahun 1998, antara Brazil dan Filipina tentang desiccated coconut pada tahun 1996-1997, antara AS dan Uni Eropa tentang nenas pada tahun 1997, antara Turki dan India terkait tekstil 
pada tahun 1999, antaa Brazil dan Kanada terkait Aircraft tahun 1999-2001, antara AS dan Malaysia terkait Shrimp dan beberapa sengketa lainya (Fathun, 2016).

Akan tetapi yang menjadi salah satu kasus adanya politik proteksionisme dalam ekonomi politik perdagangan global adalah Country of Origin Labelling (COOL) yang melibatkan politik proteksionisme AS terhadap Kanada. Sebagai bentuk kebijakan proteksionisme AS terhadap impor daging sapi Kanada, AS menggunakan slogan soft market atau non-tariff sebagai ancaman terhadap gangguan kesehatan, yang sebenarnya tujuannya adalah untuk menghindarkan impor dari negara lain. Terlihat pragmatisme kebijakan AS sebagai negara yang menggaungkan pasar bebas justru melakukan proteksionisme terhadap impor hewan ternak serta produk-produk daging (sapi dan babi) dari Kanada dimana dari pihak AS menganggap produk tersebut terkontaminasi penyakit BSE (Bovine Spongiform Encephalophaty) atau sering dikenal dengan penyakit sapi gila (mad cow disease) selain produk-produk tersebut juga dianggap terjangkit virus H1N1 atau swine flu. Kebijakan ini terlihat sangat sepihak karena belum ada penelitian lebih lanjut tentang produk. Kebiasaan pola perdagangan internasional yang dilakukan oleh AS adalah dengan menggunakan standardisasi konsitutif sebagai landasaan hukum terhadap produk impor negara lain seperti halnya terhadap Kanada.

Tentunya ini menafikan sejumlah aturan General Agreement on Tariffs and Trade (GATT) dan WTO yang sudah disepakati bersama sebagai anggota dari rezim internasional. Sehingga Kanada menjadi pihak yang dirugikan baik dalam bentuk investasi ekonomi maupun tingkat kepercayaan publik terhadap produk Kanada. Rendahnya tingkat kepercayaan tersebut akan merusak citra Kanada. Menurut Meyer et al ( 1995) dikutip (Putri dan Fjrianthi 2012:64) dalam tingkat kepercayaan bisa dibentuk melalui tiga (3) hal yaitu kemampuan (ability), kebaikan hati (benevolence), dan integritas (integrity). Hal ini berkaitan dengan reputasi atau citra yang akan di sandang oleh aktor. Tingkat kepercayaan terhadap produk ini berasal dari persepsi yang muncul dari pelaku bisnis sehingga memunculkan stigma stereotipe terhadap produk tersebut. Kondisi ini bisa dilatarbelakangi oleh jenis produk itu sendiri (representative products), karakteristik negara asal (national characteristic), aspek ekonomi dan politik (economic and political background), sejarah (history) dan kebiasaan atau tradisi (tradition). Lebih jauh Ahmed Johnson dan Boon (2004) dikutip ((Putri dan Fjrianthi 2012:64), bahwa country of origin reputation (COOR) -- country of manufacture or assembly that is identified by "made in" or " manufactured in" labels country of origin reputation merupakan instrumen evaluasi konsumen terhadap produk yaitu baik mau pun buruknya produk untuk dikonsumsi dari negara asal, kualitas produk, serta hukum kekekalannya yaitu semakin baik produk maka akan semakin baik persepsi konsumen terhadap produk tersebut.

Hal inilah yang dilakukan oleh Kanada untuk menuntut pemulihan reputasinya sehingga kasus ini diajukan ke Dispute Settlement Body (DSB) WTO dimana WTO merupakan mediator (peace maker) antar kedua pihak yang berseteru. Dengan sejumlah alasan tersebutlah makalah ini akan menjelaskan bagaimana cara AS dalam memainkan instrumen isu non perdagangan dalam ekonomi politik untuk menekan masuknya impor daging Kanada serta keterlibatan WTO dalam sengketa tersebut.

\section{Kajian Pustaka}

Internasionalisme liberal merupakan salah satu bagian dari teori dalam studi hubungan internasional untuk menganalisa sejumlah isu non-traditional security. Teori ini mengacu pada asumsi bahwa tabiat manusia itu bersifat baik serta bila tabiat baik tersebut di koordinasikan maka manusia akan saling bekerja sama untuk kemajuan bersama (Scoot Burchil dan Andrew Linklater 1996, 37). Burchil dan Linklater menjelaskan teori ini melalui tiga (3) fase 
perkembangan. Pada bagian pertama internasionalisme liberal ditinjau dari dalam yaitu isu perang dengan memahami penyebab dan pemecahannya. Asumsi teori ini adalah meniadakan perang dalam hubungan internasional apabila seluruh aktor hubungan internasional saling memahami dan menggunakan akalnya. Pada poin ini asumsi utamanya adalah bagaimana kaum liberal berupaya sekuat mungkin untuk mempromosikan perdamaian demokratis ke seluruh penjuru dunia. Alasan dari kaum liberal adalah bahwa jika dunia dalam keadaan damai maka akan tercipta kerja sama yang komprehensif antar aktor hubungan internasional. Oleh karena itu muncul asumsi kedua bahwa dengan posisi damai tersebut maka setiap aktor akan berupaya untuk mempromosikan semangat perdagangan dalam rangka menciptakan comparative advantage. Oleh sebab itulah metode diplomasi perdagangan, perimbangan kekuasaan dan keamanan kolektif adalah tujuan akhirnya yang dengan metode tersebut bisa mencegah perang antar negara.

Pada perkembangannya teori ini menuju fase internasionalisme liberal kedua yaitu dimensi ekonomi. Fase ini mengacu pada sistem ekonomi kapitalis sebagai sebuah sistem ekonomi yang baik dalam menyebarluaskan perdamaian dan kerja sama. Pola perdagangan ekonomi dengan sistem perdagangan bebas akan menciptakan masyarakat baru yang kompetitif dan menciptakan tenaga kerja nasional. Perdagangan bebas dalam bentuk swastanisasi akan menciptakan masyarakat alamiah homo economius, oleh sebab itu administrasi politik bukanlah sebuah intervensi kebijakan terhadap pasar. Memaksimalkan keuntungan merupakan tabiat dasar manusia. Dengan demikian imperialisme pasar bebas inilah yang akan mengontrol segala perilaku manusia. Penciptaan organisasi dan rezim-rezim ekonomi adalah upaya kaum liberal untuk mentranformasi moralitas universal tabiat baik manusia untuk bekerja sama. Yang ketiga, fase neo-liberal di era globalisasi. Pada dasarnya liberal dan neoliberal adalah satu kesatuan. Pada era globalisasi ekonomi peran negara lebih pada melakukan intervensi politik untuk memperlancar pasar bebas, menyediakan infrastruktur serta tidak terlalu berkepentingan terhadap pasar. Hubungan internasional adalah bentuk komersialisasi aset dan sumberdaya. Kaum neoliberal mengisyaratkan bahwa swastanisasi, deregulasi, privatisasi atau investasi asing merupakan liberalisasi finansial yang akan mendukung masyarakat yang kompetitif. Sedangkan perilaku negara yang protektif terhadap industri dalam negeri yang tidak kompetitif adalah sebuah kejahatan.

Dalam paradigma teori liberal yang kemudian berubah menjadi neoliberal dalam kenyataan tidak bisa menafikan peran serta pengaruh dari sejumlah rezim internasional. Rezimrezim perdagangan internasional akan mempermudah setiap negara untuk saling bekerja sama dan hal ini menjadi ciri negara modern. Institusionalisme neoliberal pada dasarnya adalah ideologi dimana negara dengan daya politiknya berupaya untuk menciptakan hegemoni pasar dan keterbukaan negara terhadap autarki. Ketergantungan negara pada perdagangan internasional akan menciptakan perdamaian, penciptaan identitas, penciptaan keadilan, kesejahteraan dengan pola kompetitif pasar (Hill dan Pettifort 2009, 93).

Pada dasarnya manusia adalah makhluk rasional yang ingin menuju pada modernitas kemajuan. Sehingga terjadinya kerja sama antara aktor hubungan internasional memudahkan menciptakan manusia yang lebih baik (Jackson dan Sorenson 2014, 213). Kaum liberal berasumsi pada liberalisme sosiologi yakni menjaga keterhubungangn erat antara negara dan masyarakat serta aktor non-pemerintah dalam mendukung terbentuknya pasar yang bersaing. Liberalisme interdependensi mengasumsikan bahwa ketergantungan terhadap pasar dan perdagangan akan menciptakan masyarakat tanpa konflik. Lebih lanjut liberalisme institusionalisme mengusulkan penciptaan rezim-rezim internasional seperti WTO, IMF, Bank Dunia sebagai lembaga yang bisa menjadi mediator untuk menciptakan pasar yang terbuka. Kaum liberal khususnya liberalisme demokratik republikan percaya bahwa hanya dengan 
pemerintahan yang demokratis semua kondisi tersebut bisa tercapai. Negara harus menciptakan kebijakan luar negeri yang kooperatif sebagai instrumen mengejar kepentingannya.

Rezim internasional diciptakan sebagai aktor yang menyediakan rule-driven yang bersifat regional maupun supranasional. Organisasi rezim internasional mengupayakan penciptaan aturan-aturan formal maupun tidak formal dalam tata kelola pasar yang baik dan kompetetitif. Rezim internasional ini akan menekan perilaku aktor, menciptakan harapan dengan sejumlah norma dan kebijakan struktural yang menuntut negara tergantung pada perjanjian-perjanjian baik bilateral maupun multilateral yang telah disepakati bersama (Carlsnaes 2013, 394).

WTO adalah rezim yang terimplementasi dari teori liberalisme dalam upaya menciptakan perdagangan bebas dan terbuka. WTO merupakan sebuah organisasi perdagangan internasional yang dibentuk pada tanggal 15 April 1994 di Marakesh, Maroko setelah perundingan panjang mengenai perdagangan dunia yang disebut Putaran Uruguay dan hingga kini telah menaungi 159 negara di dalamnya. Organisasi ini berfungsi sebagai forum bagi kerja sama internasional dalam hal kebijakan perdagangan internasional.

Dalam pelaksanaan tugasnya, WTO berupaya untuk membangun skema perekonomian yang sehat bagi semua negara anggota dengan cara membentuk kerangka kebijakan perdagangan yang dapat memfasilitasi kepentingan setiap negara dalam hal perdagangan internasional. Kerangka untuk mengatur kebijakan perdagangan ini tertuang dalam prinsipprinsip WTO yang menjadi dasar dari sistem perdagangan multilateral. Selain itu, WTO juga memiliki perangkat pengambilan keputusan dalam rapat-rapat penting antar anggota.

Prinsip penting dalam WTO menyangkut (1) Non-discrimination dimana terdapat dua unsur penting dalam prinsip ini yaitu national treatment atau upaya mendiskriminasi dengan sengaja partner dagang, serta unsur most-favored -- adanya spesialisasi dalam partner dagang mengangkut pajak, tarif, dan sebagainya; (2) Reciprocity yaitu setiap aktor bisa melakukan renegosiasi terhadap hambatan-hambatan perdagangan; (3) Binding and Enforceable Commitment dimana setiap mekanisme tarif yang telah di tetapkan WTO berlaku secara hukum dan mengikat anggotanya; (4) Transparency yaitu WTO menciptakan aturan yang terbuka terhadap setiap anggotanya. Serta (5) Safety Value bahwa negara bisa melakukan proteksionisme terhadap ekspor-impor barang apabila tidak sesuai kebutuhannya (Winarno 2007, 44).

\section{Hasil dan Pembahasan}

\subsection{Proteksionisme Dalam Perdagangan Internasional}

Munculnya kontroversi kebijakan proteksionisme menyita banyak perhatian sejumlah negara karena sudah menjadi praktek dan hukum legal dalam percaturan ekonomi politik kontemporer. Proteksionisme mengandung dua makna yakni pertama, merupakan paham yang menekankan usaha pemerintah untuk melindungi dunia usaha. Kedua, merupakan usaha pemerintah untuk memberikan hambatan-hambatan perdagangan seperti tariff kuota, pajak, dan lain-lain untuk melindungi industri dalam negeri dalam perdagangan ekspor atau impor dari produk negara lain (Sumadji et al. 2006, 352). Proteksionisme diartikan sebagai kebijakan ekonomi yang menghambat perdagangan internasional melalui tarif bea masuk impor (tariff protection), pembatasan kuota, pemberian subsidi (non-tariff protection), atau sejumlah hukum nasional sebagai instrumen untuk menekan impor bahkan aturan fundamental dengan melarang masuknya impor (Friedrich List 1996, 306).

Pada awalnya politik proteksionisme ini dikemukakan oleh Alexander Hamilton, Menteri Keuangan pertama Amerika Serikat dalam Reports of of Manufactures tahun 1791 
dimana menurutnya negara sudah seharusnya melakukan proteksionisme terhadap industriindustri muda (infant industry) yang belum memiliki keterampilan bersaing dengan masuknya produk-produk dari luar negeri sehingga akan menciptakan kecenderungan menutup akses bagi industri muda untuk turut andil dalam komptesisi pasar bebas akibat "tergilas" oleh produkproduk asing. Artinya infant industry ini belum memiliki kapabilitas dan stabilitas (KPPU 2010, 7).

Kemudian pemikiran itu dikembangkan oleh Friedrich List bahwa kemampuan sebuah industri menghasilkan produksi sendiri atau barang produksi lebih utama ketimbang hasil produk itu sendiri. Maksudnya adalah setiap industri muda harus diberi kesempatan untuk belajar memproduksi, mengelola pasar, mengelola usaha, mengelaborasi barang produksi agar bisa menghasilkan produk yang kompetitif sehingga peran negara yang memiliki power adalah melakukan proteksionisme. Kebijakan ini dilakukan oleh Inggris, AS, dan Jerman pada abad ke 19, dimana pada saat itu intervensi negara sangat besar terhadap pasar sehigga industri muda tidak bisa head to head dengan industri yang sudah matang. Pada saat itulah proteksionisme digunakan oleh negara-negara tersebut untuk memajukan industrinya (Friedrich List,1966).

Kebijakan proteksionis cenderung digunakan sejumlah negara, misalnya kebijakan pembatasan kuota yang dilakukan AS di era 1970-an. Ketika itu terjadi kenaikan harga bahan bakar dan masyarakat AS lebih memilih membeli mobil berukuran kecil yang merupakan produk dari Jepang dengan tujuan melakukan penghematan terhadap bahan bakar. Demi kepentingan melindungi industri otomotif domestiknya, AS mengeluarkan kebijakan proteksionis dengan menetapkan kuota terhadap jumlah mobil Jepang yang diperbolehkan masuk ke AS. Kasus lainnya bagaimana kekhawatiran AS terhadap negara-negara yang menerapkan pajak pertambahan nilai (PPN) dimana AS merasa dirugikan oleh hukum tersebut sebab setiap AS menjual produknya akan diberlakukan hukum pajak tersebut. Dalam penjualan produk ke Indonesia misalnya maka secara tidak langsung produsen harus membayar PPN, namun kontradiksinya adalah ketika Indonesia menjual produknya ke AS yang tidak memberlakukan PPN, Indonesia tidak akan membayar biaya PPN. Paradoks proteksionisme ini harus menjadi perhatian khusus oleh WTO supaya tidak mematikan semangat perdagangan bebas serta konflik global low politic.

\subsection{Studi Kasus}

Proteksionisme perdagangan pernah merajalela pada era 1930-an. Pada tahun itu, antara tahun 1929 dan 1933, perdagangan di seluruh dunia berkurang hingga 54\% akibat berbagai hambatan perdagangan yang diterapkan oleh salah satunya AS. Tahun 1970-an dan 1980-an, saat itu proteksionisme perdagangan semakin menyita perhatian. Ada tiga faktor yang bisa menjelaskan mengapa ini dilakukan yaitu pertama, proteksionisme akibat hegemoni AS di dalam aturan GATT (WTO). Kondisi ini menitikberatkan pada bagaimana peran AS sebagai negara yang mengaku demokratis dan kapitalis liberal harus menjadi contoh untuk menjamin terciptanya perdagangan yang bebas dan adil. Karena hegemoni menjadi momok menakutkan, maka AS mencoba mencari negara yang bisa memikul beban itu agar tetap menjamin berjalannya sistem perdagangan internasional sebagai aliansi ekonomi perdagangan. Dengan hegemoni pada aliansi ekonomi seperti APEC, WTO, Bank Dunia dan IMF merupakan cara AS untuk tetap eksis dalam perdagangan internasional. Kedua, hegemoni politik dan ekonomi AS mulai berkurang seiring dengan munculnya pengaruh politik dan ekonomi negara-negara China, Uni Eropa, Jepang, dan negara-negara industri baru dalam ekonomi politik global apa lagi dengan pergeseran sistem internasional pada kawasan Asia Pasifik. Ketiga, munculnya tekanan dari penganut paham merkantilisme bahwa sudah sewajarnya negara menjadi agresif dalam ekonomi politik global untuk menjaga dominasinya serta tetap fokus pada perlindungan 
kepentingan negara terutama industri baru walaupun tetap harus fokus pada ekonomi politik internasional. China telah melakukan ekspansi ekonomi dengan terlibat ASEAN Plus Three dan sejumlah aliansi lainya menjadikan AS khawatir akan percepatan ekonomi China. Krisis AS pada tahun 2008 membuktikan kebangkitan ekonomi Asia (China, Jepang, Korea Selatan serta empat naga kecil ASEAN yaitu Singapura, Malaysia, Brunei serta Indonesia) menjadi tantangan tersendiri bagi AS dalam siklus politik perdagangan internasional. Akibatnya dalam upaya memperluas ekspansi ekonomi maka kebijakan proteksionisme merupakan salah satu jalan untuk tetap menjaga kestabilan ekonomi walaupun negara tersebut menggunakan perspektif neoliberal.

Kebijakan proteksionisme cenderung akan mencederai slogan semangat sistem perdagangan bebas. Kebijakan ini cenderung sulit untuk dihapuskan bahkan bentuk proteksionisme baru justru lahir berupa hambatan non-tarif yang disandingkan dengan penggunaan isu-isu low politic seperti kesehatan, lingkungan, perlindungan buruh, dan sebagainya. Fenomena ini digunakan untuk mengaburkan tujuan negara dalam melindungi pasar domestik dari masuknya barang impor. Kebijakan proteksionis juga berdampak pada konsumen karena mereka dirugikan akibat ketersediaan pilihan terhadap produk-produk di pasar. Kebijakan proteksionis akan cenderung melumpuhkan kreativitas, inovasi produk negara lain yang sebenarnya hal tersebut tidak boleh terjadi. Akibatnya berdampak pada produsen dan konsumen, terutama akan melumpuhkan usaha produsen.

\subsection{Sengketa Country of Origin Labelling (COOL) sebagai Proteksionisme AS terhadap Kanada}

Sengketa perdagangan yang melibatkan AS dan Kanada merupakan masalah yang perlu diselesaikan sehingga tidak mengabaikan tatanan sistem perdagangan internasional. Ketegangan antara kedua negara memperlihatkan bagaimana ketegangan dua paradigma besar dalam ekonomi politik internasional yakni internasionalisme liberal dan merkantilisme. Dalam prakteknya sejumlah negara mengharapkan keterbukaan pasar yang bebas (free trade for open market) namun realitasnya negara melakukan proteksi untuk melindungi kepentingan nasionalnya.

Perilaku AS untuk menghindari impor livestock hewan ternak serta produk-produk daging (terutama sapi dan babi) dan olahannya dari Kanada menunjukkan bagaimana upaya negara tersebut menggunakan kebijakan proteksionisme sebagai instrumen ekonomi politik untuk menciptakan ketahanan pangan domestik yang bersumber pada stabilitas pasar domestik dengan memperketat masuknya produk dalam negerinya. Munculnya isu low politic sebagai bentuk proteksionime menambah variasi baru dalam perilaku negara untuk melindungi industri domestiknya. Misalnya mewabahnya isu-isu non trade seperti kesehatan, agama, perlindungan buruh, dan lingkungan menunjukkan bagaimana proteksionisme masih dan kemungkinan akan terus menjadi instrumen ekonomi politik standar ganda dalam perdagangan internasional. Oleh sebab itu, menciptakan sistem perdagangan internasional murni bebas dan adil bukan hal yang mudah. Munculnya isu-isu seperti kesehatan, agama, perlindungan buruh, dan lingkungan menjadikan perdagangan internasional lebih dinamis. Isu-isu baru tersebut merupakan representasi dari low conflict issues antar negara di masa kini. Artinya dahulu isu-isu tersebut tidak menjadi prioritas negara dan kurang mendapat perhatian namun sekarang bisa saja semakin mengemuka.

Dalam kasus tersebut setiap negara tidak memikirkan secara komprehensif bagaimana pengaruh kesehatan terhadap bisnis internasional baik $\mathrm{G}$ to $\mathrm{G}$ (Government to Government) maupun B to B (Business to Business) atau G to B (Government to Business). Kesehatan sebagai salah salah unsur penting dalam standarisasi produk yang masuk dalam praktek 
perdagangan internasional, haruslah menjadi salah satu poin renegosiasi antar aktor agar tidak saling merugikan. Namun yang perlu diperhatikan adalah dualisme hukum penerapan standar kesehatan di setiap negara sangat berbeda dan cenderung setiap eksportir dan importir harus mengikuti standar yang diterapkan oleh negara tujuan.

Country of Origin Labeling (COOL) merupakan sebuah peraturan pelabelan yang disahkan oleh hukum perundang-undangan AS yang mewajibkan para pengecer bisa dikatakan negara/perusahaan untuk mencantumkan label negara asal pada berbagai jenis produk makanan, dengan tujuan memberitahu konsumen mereka mengenai informasi sumber makanan tertentu, seperti daging sapi segar, daging babi dan domba (kecuali produk olahan). AS mengajukan perluasan COOL sebagai aturan hukum untuk menjaga tingkat keaslian, pelebelan, asal produk, jenis produk, cara penyembelihan seperti daging sapi, babi, domba serta ayam. Hukum ini untuk menciptakan ketahanan pangan agar setiap produk yang dipasarkan tidak merugikan konsumen. Aturan ini dikeluarkan oleh United States Departement of Agriculture Food Safety and Inspection Service untuk menciptakan standarisasi hukum sesuai 7 CFR Bagian 60 dan 7 CFR Part 65 untuk semua komoditas yang berlaku pada 16 Maret 2009.

Pada peraturan COOL pada 29 September 2008, badan legislatif menyertakan lebih banyak jenis makanan seperti buah-buahan segar, kacang-kacangan, dan sayuran. Semua ternak yang ada di AS pada atau sebelum 15 Juli 2008 yang tetap berada di negara ini akan dianggap sebagai ternak asal AS. Label "produk Amerika Serikat" hanya dinyatakan berlaku untuk hewan yang secara khusus lahir, diternakkan dan dipanen di AS.

Terdapat tiga kategori label lainnya, yaitu: (1) untuk hewan yang lahir dan atau diternakkan di negara lain yang kemudian dipanen di AS dilabeli sebagai produk multi-asal dimana semua negara yang bersangkutan wajib untuk diidentifikasi terlebih dahulu; (2) produk daging yang diimpor dari negara lain dilabeli sebagai produk negara tersebut; (3) untuk hewan yang diternakkan di negara lain dan diimpor ke AS untuk segera dipanen.

Ketika aturan COOL diresmikan pada tanggal 23 Mei 2013 yang berlaku kepada seluruh retailer ternyata aturan tersebut hanya efektif sampai bulan September 2013, dimana aturan ini hanyalah bisa mewajibkan adanya identifikasi dan verifikasi terhadap urat daging yang memiliki asal berbeda terutama ketika daging itu disembelih. Pada bulan yang sama yaitu September 2013, National Grocers Association (NGA) mengajukan sebuah nota surat kepada United States Department of Agriculture (USDA) agar tidak langsung menjalankan aaturan hukum COOL sebelum adanya putusan final dari WTO tentang pengaduan Kanada kepada AS. Pada kebijakan fiskal 2014 barulah United States Department of Agriculture (USDA) menerapkan hukum COOL dan sudah berlaku sampai sekarang. Akan tetapi pada 23 November 2013 para pengecer sudah diminta menunjukan asal muasal dan identifikasi terhadap daging yang mereka dagangkan.

Pengecer harus mengidentifikasi negara tertentu di mana hewan itu lahir, diternakkan dan disembelih. Aturan pelabelan mencakup pemotongan otot dari daging sapi, ayam, babi, domba, dan kambing, serta yang sementara diproses di luar daging olahan. Sementara pihak Kanada sedang mengajukan banding tentang hukum tersebut yang akan dipanelkan pada 9 Januari 2014 di Peradilan Federal. Asumsi diberlakukannya hukum COOL ini agar setiap konsumen yang ada di AS mengetahui dengan jelas produk yang mereka konsumsi. Tetapi bisa juga aturan tersebut hanyalah alasan AS bahwa warga AS hanya bisa mengkonsumsi daging yang diternakkan atau dikembangkan di negara itu (protection for domestic policy product).

Kemunculan Canadian Cattlemen's Association, Canadian Pork Council, The American Association of Meat Processors, American Meat Institute (AMI), North American Meat Association, and Southwest Meat Association, National Cattlemen's Beef Association, National Pork Producers Council, merupakan sejumlah pihak yang kurang setuju dengan diberlakukanya hukum COOL. Secara sederhana pemberlakuan COOL akan menguntungkan 
konsumen akan tetapi bagi pengusaha dan pebisnis akan cenderung menyulitkan untuk mencampurkan produk olahan daging yang berasal dari negara lain dan mengakibatkan industri ternak cenderung sulit berkembang. Oleh sebab itu mereka mengajukan tindakan peradilan.

Kemudian Kanada sebagai pihak yang dirugikan mengatakan terjadi pelanggaran terhadap perjanjian perdagangan dan mengajukan banding atas aturan COOL milik USDA kepada WTO. Pada tahun 2011, WTO sebagai rezim yang bertanggung jawab atas konflik perdagangan menyetujui hal itu dan memberikan perintah kepada AS untuk bisa membuktikan segala tuduhannya terhadap proteksionisme impor daging Kanada terkait munculnya aturan COOL oleh USDA.

\subsection{WTO Sebagai Peace Maker Dalam Sengketa Perdagangan Internasional}

Masalah politik proteksionisme merupakan sebuah dilema bagi suatu negara (state dilemma), yaitu adanya tuntutan konsistensi dan profesionalitas tapi tekanan kebijakan politik domestik terus memacu dan mengharuskan negara melakukan low politic protectionism yang disebut oleh Jagdish Bhagwati sebagai hukum kekekalan proteksionisme. Artinya kebijakan proteksionisme negara tidak bisa dihilangkan dalam praktek ekonomi politik internasional dan seolah sudah menjadi lumrah.

Hendrawan Supratikno anggota Komisi VI DPR RI mengatakan bahwa kebijakan negara ketiga terlibat dalam persaingan pasar bebas memang harus menerima kenyataan konsekuensi dilema proteksionisme. Pragmatisme negara melalui kebijakan proteksionisme menunjukkan keseriusan negara untuk terlibat dalam pasar yang terbuka. Yang harus disadari negara adalah jangan terjebak pada "kapitalisme semu" yang menganggap proteksionisme adalah cara negara untuk melindungi pasar domestik. Proteksionime negara sudah menjadi hal lazim tetapi yang perlu ditekankan adalah proteksionisme jangan sampai tanpa periodisasi atau "cek kosong". Maksudnya adalah negara hanya memberikan keuntungan ganda kepada sejumlah rentenir yang membuat negara tidak berkembang. Yang perlu dilakukan adalah negara harus menggunakan proteksionisme sebagai bagian integrasi dan perkembangan industrialisasi dengan melakukaan proteksionisme selektif (KPPU 2010, 4-5). Jadi kebijakan proteksi sebuah negara adalah kebijakan politik yang punya potensi negatif dan positif tergantung pada tata kelola pengambil kebijakan dalam memanfaatkan kebijakan tersebut.

Menyelesaikan sengketa dagang harus melalui prosedur yang telah ditetapkan. Pergantian GATT (General Agreement on Tariff and Trade) menjadi WTO diasumsikan GATT tidak punya "gigi" dalam menyelesaikan sengketa dagang dalam perdagangan internasional WTO dengan aturannya yaitu understanding on rules and prosedures governing settlement of dispute (DSU) merupakan aturan resmi dalam menyelesaikan sengketa dagang internasional. Sesuai pasal 6 DSU bahwa setiap negara yang memiliki masalah dagang dengan partner dagangnya bisa mengajukan masalah ke WTO diawali dengan automaticity melalui tiga tahap yakni diplomasi bilateral yang apabila gagal maka dilakukan diskusi panel, namun apabila belum memuaskan setiap negara bisa mengajukan banding kepada lembaga banding atau appellate body yang terdiri atas tujuh pakar hukum perdagangan internasional sebelum dibawa pada dispute settlement body (DSB) (Djumala 2004, 227-228). Langkah-langkah inilah yang di ambil oleh Kanada terhadap AS terkait impor daging yakni dengan pendekatan negosiasi untuk menciptakan best alternative solution diantara kedua negara.

Pada Desember 2008 dan Juli 2009 dalam Summary DSB 384, 386 dengan Canada, Mexico (Complainants) dan United State (Respondent) tuntutan TBT Arts, Kanada mengajukan pertemuan dengan AS terkait proteksionisme COOL. Akan tetapi hasil yang didapatkan nihil. Kemudian pada Oktober 2009, Kanada kembali mengajukan permasalahan ini ke WTO yang memiliki wewenang sebagai peacemaker, kedua negara menginginkan adanya diskusi panel 
dengan AS untuk menyelesaikan masalah (dispute settlement panel). Pihak AS menyesalkan tindakan kedua negara yang mengadukan masalah tersebut kepada WTO. Alasannya adalah AS merasa telah membuat hukum COOL tentang kesehatan makanan jauh sebelum terbentuknya WTO yakni pada tahun 1946 sebelum diubah menjadi USDA pada tahun 2002 dan 2008 dan terbentuk aturan final pada tahun 2009. Sedangkan Kanada dan Meksiko tetap kukuh bahwa AS telah melanggar Kesepakatan Umum dalam Tarif dan Perdagangan (GATT) tahun 1994 yang menyatakan bahwa produk impor seharusnya tidak dibedakan dengan produk lokal. Dalam perubahannya menjadi WTO tentunya tindakan AS juga melanggar prinsipprinsip WTO seperti non-discrimination, reciprocity dan kemudian pada 19 November 2009 dibentuklah Badan Penyelesaian Masalah atau Dispute Settlement Body (DSB).

Perseteruan berlanjut pada 18 November 2011, dimana dibentuk diskusi panel oleh WTO dan sebagai hasil kajian memutuskan AS bersalah dengan melanggar dua artikel dari kesepakatan WTO pada Teknis Pembatasan dalam Perdagangan (TBT) dan ketentuan dasar GATT. Pelanggaran ini menyangkut artikel 2.1 bahwa setiap negara dilarang untuk mendiskriminasi produk dagang dari negara lain terhadap produk lokal atau domestik. Akibatnya adalah merugikan produsen impor serta merugikan kemampuan kompetitif industri ternak sedangkan informasi yang diberikan kepada konsumen tidak proporsional dan dinyatakan tidak sah oleh artikel 2.1. Selain itu ada ketidakkonsistenan AS terhadap Artikel 2.2. karena AS tidak dapat memberikan alasan tujuannya dan legitimasi untuk memberikan label pada produk daging tersebut. AS dinyatakan tidak konsisten dan juga tidak bisa menggunakan hukum COOL atau bisa dikatakan bahwa tata kelola AS terhadap hukum COOL berada dalam posisi tidak wajar (proteksi) dan tidak menyediakan informasi yang cukup kepada konsumen. DSB menindak lanjuti laporan dari DSB pada 23 Juli 2012, meskipun terbukti bersalah, DSB tidak memberikan informasi yang spesifik terkait yang harus dilakukan oleh AS sebagai bentuk pertanggungjawabannya.

Dalam aturan WTO setiap negara yang telah terbukti bersalah melalui DSB maka akan diberi jangka waktu satu tahun untuk memperbaiki segala sistem perdagangannya. WTO sebagai rezim yang memiliki wewenang akan hal tersebut telah membuat aturan-aturan tersebut agar disepakati bersama seperti dalam prinsip Binding and Enforceable Commitment maksudnya setiap mekanisme tarif yang telah ditetapkan WTO berlaku secara hukum dan mengikat anggotanya serta prinsip transparency dimana WTO menciptakan aturan yang terbuka terhadap setiap anggotanya. Sedangkan AS diberi jangka waktu 18 bulan saja untuk membenahi segala aturan COOL namun Kanada tetap merasa bahwa jangka waktu tersebut sudah terlalu lama. Menurut Kanada jangka waktu 6 bulan sudah cukup bagi AS untuk membenahi sistem perdagangannya. Dengan demikian, WTO seharusnya turun tangan untuk menindak AS, sebab jika memang tidak terjadi Kanada memiliki hak istimewa untuk melakukan hal yang sama sesuai dengan pasal 22 ayat 3 DSU yakni mendiskriminasikan mitra dagang terhadap pasar domestiknya.

WTO sebagai peace maker dikatakan sebagai arbitrator dalam pendekatan negosiasi dalam sengketa dagang antara AS dan Kanada. Dari hasil keputusan di atas menunjukan AS sepertinya memaksakan kehendaknya untuk menerapkan aturan hukum kepada negara lain yang mengirimkan barangnya ke negara tersebut. Pola ini sesuai dengan karakter negosiasi yang masih dipegang oleh AS yaitu hardstyle. Hardstyle artinya model negosiasi yang selalu memaksakan kehendak, menekan, manipulatif, dan ingin menang sendiri yang dalam istilah konflik digambarkan sebagai situasi "win-lose". Pola ini tidak sesuai dengan karakter WTO sebagai peace maker yang mewadahi semua kepentingan negara anggotanya. Itu artinya WTO sebagai peace maker harus menjadi aktor yang mengimbangi untuk melahirkan best alternative decision. 
Di sisi lain, Kanada yang secara geografis dekat dengan AS dan merupakan mitra dagang AS diperlakukan tidak adil oleh AS sebagai negara yang sama dalam struktur keanggotaan WTO. Kondisi ini melihat tipe negosiasi yang digunakan oleh Kanada lebih bersifat blue style. Blue style dalam arti Kanada ingin menjadi mitra yang baik bagi AS terkait impor daging. Blue style berhubungan dengan karakter aktor yang menitikberatkan pada sifat kooperatif, kompromistik, saling menguntungkan dan transformatif serta konstruktif. Dorongan rivalitas kedua negara dalam proses negosiasi menunjukkan bahwa terdapat distorsi dimana setiap negara membawa kepentingan masing-masing dan tetap konsisten dengan kepentingan tersebut. Akibatnya terbentuk dua pola konflik di antara kedua negara yaitu AS dengan "saya memaksa kamu untuk melakukan apa yang saya mau", namun di sisi lain Kanada dengan "model saya dan kamu harus melakukan sesuatu yang menguntungkan kita berdua". Rivalitas ini tidak bisa menemukan jalan damai hingga harus melibatkan WTO sebagai peace maker dan beberapa negara lain yang juga anggota WTO sebagai peninjau dan pemberi saran dalam bentuk negosiasi multilateral.

Sengketa kedua negara yang awalnya hanya terkait kasus kesehatan terpolarisasi hingga melibatkan aktor lainnya. Bahkan sepertinya AS tetap konsisten menerapkan pemaksaan aturan USDA kepada Kanada. AS sendiri tidak mampu membuktikan dengan baik hasil tuduhan tersebut. Akibantnya bisa disimpulkan bahwa model kebijakan AS ini merupakan pelaksanaan power structure untuk menekan masuknya produk daging Kanada. Kebijakan proteksionis ini justru membuat AS menjadi malu dan menciptakan ketidakpercayaan (distrust) bagi beberapa negara lainya. Power structure ini menjadi instrumen bagi AS untuk membenarkan tindakannya dengan alasan kesehatan. AS menjadikan aturan USDA sebagai enforcement untuk tetap memaksakan kehendaknya.

Dalam rivalitas model negosiasi yang terjadi kedua negara akhirnya mampu merubah style masing-masing yang menitik beratkan pada style konstruktif, dimana kedua negara sepakat untuk tetap meninjau kembali aturan tersebut sehingga tidak merugikan Kanada dan dari sisi AS juga tidak merugikan industri dalam negerinya.

\section{Kesimpulan dan Rekomendasi}

Kebijakan proteksionisme negara terhadap negara lain pada dasarnya melanggar konstitusi GATT yang sekarang menjadi WTO. Kebijakan proteksionisme ini ditujukan untuk melindungi industri muda yang ada dalam pasar domestik agar ke depan bisa bersaing dengan industri asing. Namun segi pragmatis kebijakan tersebut justru dimanfaatkan oleh sejumlah aktor/perusahaan untuk menjadikan kapitalisme semu negara. Artinya tidak ada konsistensi negara terhadap komitmen untuk menjadikan pasar sebagai tujuan utama ekonomi politik. Oleh karena itu disadari bahwa proteksionisme memang diperlukan namun yang harus di sadari adalah proteksionisme yang bersifat selektif. Maksudnya adalah harus ada periodisasi tentang munculnya kebijakan tersebut. Sebab jika tidak, justru menjadi sebaliknya yaitu industri dalam negara akan manja sebab selalu dilindungi oleh negara.

Kebijakan proteksionisme seharusnya disikapi sebagai cara untuk menjadikan integrasi ekonomi dan industrialisai yang lebih kompetitif dan inovatif yang jika dipandang positif justru kebijakan ini tidak merusak tatanan ekonomi politik terhadap pasar. Yang perlu dilakukan adalah menghasilkan produk yang bersaing, kompetitif, inovatif, memperbaiki infrastruktur, tata kelola admistrasi negara, tata kelola manajemen perusahaan agar ketika muncul kebijakan proteksi negara dengan sejumlah pandangan dan asumsinya bisa menjadi pelajaran agar setiap infant industry mempersiapkan diri dan produk terbaiknya untuk di impor atau di ekspor keluar. Karena pada dasarnya hukum ekonomi politik setiap negara bisa menjadi pelaku ekspor dan juga bisa menjadi pelaku impor. 
Proteksionisme yang dilakukan oleh AS terhadap Kanada merupakan upaya mendiskriminasi perdagangan sebagai upaya untuk menghindari kompetisi industri pasar bebas. AS yang selalu lantang menyuarakan pasar bebas ternyata dalam beberapa kasus perdagangan internasional tidak menunjukkan konsistensinya sebagai negara demokrasi dalam bidang perdagangan internasional. Walaupun terkesan memang sangat pragmatis akan tetapi negara sebesar AS seharusnya tidak perlu takut dengan kompetisi pasar bebas. Hal tersebut membuktikan bahwa ada konflik dalam ekonomi politik internasional terutama dalam bidang perdagangan. AS dengan segala kemampuan hegemoninya berupaya menerobos aturan GATT/WTO yang sudah menjadi rezim internasional dalam perdagangan global.

Keterlibatan WTO melalui pendekatan negosiasi dalam menyelesaikan sengketa perdagangan merupakan upaya WTO dalam menciptakan siklus perdagangan internasional yang kompetitif, adil, bebas tanpa ada diskriminasi. Namun sebagai intervensionis seharusnya WTO berani memberikan sangsi hukum kepada AS sebagai negara yang selalu melanggar konstitusi perdagangan. Sebab hal ini bisa menjadi preseden buruk bagi negara lainya dalam menciptakan siklus yang sama dalam perdagangan internasional. Sengketa COOL antara AS dan Kanada hanyalah sebagian kecil dari banyaknya sengketa dagang yang dilakukan oleh beberapa negara. Dalam publikasi data WTO, AS merupakan salah satu negara yang paling banyak melakukan proteksi produk dan terlibat dengan beberapa negara. Oleh karena itu pendekatan negosiasi sampai saat ini masih menjadi pendekatan yang paling efektif dalam menyelesaikan sengketa dagang di antara negara-negara anggota WTO. 


\section{DAFTAR PUSTAKA}

\section{Buku}

Burchill, Scoot, Andrew, Linklater. (1996). Theories of International Relations. Terj. Bandung: Nusamedia.

Carlsnaes, Walter, dkk. (2013). Handbooks of International Relations. Terj. Bandung: Nusamedia.

Christhophorus, Barutu. (2007). Ketentuan Antidumping, Subsidi dan Tindakan Pengamanan (Safeguard) dalam GATT dan WTO. Cet 1. Bandung: Citra Aditya Bakti.

Djumala, Darmansjah. (2004). Hubungan Internasional Percikan Diplomat Indonesia, Jakarta: Gramedia Pustaka Utama.

Frieden, Jeffry A., dan David A. Lake. (2000) International Political Economy: Perspective on Global Power and Wealth. Fourth Edition, St. New York: Martin's Press.

Jackson, Robert dan Georg Sorensen. (2014). Pengantar Studi Hubungan Internasional, Edisi Revisi Terbaru. Yogyakarta: Pustaka Pelajar.

Leonni, Rizky Putri dan Fajrianthi. (2012). Jurnal Psikologi Industri dan Organisasi. Vol. 1 No. 02, Juni.

List, Friedrich. (1966). The National System of Political Economy. E-book. New York: Kelley. Lumumba, Patrice. (2012). Negosiasi dalam Hubungan Internasional. Yogyakarta: Pustaka

Pelajar.

Fathun, Laode Muhamad. (2016). Transformasi Isu-Isu Hubungan Internasional Pasca Perang Dingin Di Era Globalisasi. Yogyakarta: Magister Hubungan Internasional, Universitas Muhammadiyah.

Sumadji et al. (2006. Kamus Ekonomi. Jakarta: Wacana Intelektual.

Streans, Hill dan Lloyd Pettifort. (2009). Hubungan Internasional Prespektif dan Tema, Yogyakarta: Pustaka Pelajar.

Winarno, Budi. (2007). Globalisasi dan Krisis Demokrasi. Yogyakarta: MedPress.

\section{Website}

www.wto.org/disputes di akses pada 02 oktober 2016)

http://www.fpif.org/reports/kicking_away the ladder_the_real_history_of_free tragedi akses pada tanggal 02 oktober 2016 )

http://www.ams.usda.gov/rules-regulations/cool di akses pada 02 oktober 2016) (

Farmers' Legal Action Group, Inc.,'Understanding How Country of Origin Labeling Program Affect Farmers", www.flaginc.org di akses pada 02 oktober 2016 